\title{
Una didáctica para la formación docente. Dimensiones y principios para la enseñanza ${ }^{(1)}$
}

\author{
María de Carmen Castells
}

Baraldi, Bernik, Díaz (2012). Una didáctica para la formación docente. Dimensiones y principios para la enseñanza. Santa Fe: Ediciones UNL.

Presentar una producción de un grupo de compañeras, además de hacerme sentir horada, me permite, junto a ellas, continuar su escritura. Un acto de atrevimiento que sin permiso inscribirá en el texto nuevas preguntas porque su lectura me involucra como sujeto del campo del saber de la Didáctica en la Formación Docente, tarea que venimos compartiendo desde hace ya muchos años, no sin esfuerzos, errores, fracasos, logros, críticas y autocríticas.

El recorrido elegido en este libro, producto de un proceso de investigación fue analizar, entre otras, condiciones de producción y categorías de lo que las autoras, junto a otros pensadores, denominan "alternativas". Me detengo allí para retomar, como lo hacen ellas, el/los significados de la palabra alternativa: el recambio de una cosa por otra, la transformación del orden existente. En este último sentido, alternativa y acontecimiento hacen estallar lo que venía siendo, trastoca un orden establecido, establece nuevas relaciones, instaura nuevas coordenadas para analizar lo real desde palabras y significados que recogen experiencia de una situación y de un presente.

Allí una pregunta que nos alcanza a los profesores de Didáctica: qué herramientas metodológicas, discursivas, ponemos a disposición de los futuros docentes para dar cabida a aquello que, si bien debe trascender la anécdota y lo descriptivo, al mismo tiempo debe habilitar espacios para pensarlas, escribirlas y comunicarlas ya sin pretensión de generalización. Cómo recoger las alteraciones de las alternativas sin totalizarlas, esto es, sin fosilizarlas, en estabilizaciones que sólo se guardan para sí el derecho de repetirse en cualquier situación, sin tocar los modos que la Didáctica ha guardado para sí en sus prácticas de producción de conocimiento. 
Recupero aquí el interrogante por la historicidad y por la temporalidad del presente que mis colegas destacan en sus escritos. Interrogante que se reitera en cada una de las experiencias narradas. $Y$ digo que pensar el presente nos remite a una temporalidad que nos incluye a nosotros mismos, no como un tiempo que se pone delante para mirar, sino como lo que nos inscribe en una subjetividad desde la que hablamos, desde donde nos vemos a nosotros y a los otros.

Abro lo que me interpela a mí misma: ¿Qué prácticas seguimos manteniendo para nombrar y escribir las prácticas didácticas? En ese sentido, las unidades de análisis delimitadas en el libro se potencian como experiencias generadoras de experiencias que no están allí para colocarnos del lado del espectador, sino que nos procuran prácticas que instalan nuevos modos de lectura, nuevos horizontes de visibilidad para mirarnos en la temporalidad del presente. Ellas no sólo deberían instalar rupturas por fuera de nosotros, en los alumnos o en los docentes, otros, sino en nosotros mismos, enseñantes de Didáctica, porque permiten reencontrarnos en aquellas categorías de la modernidad que pretendemos poner a consideración crítica.

A este respecto, la idea de experiencia nos compromete porque altera también nuestro modo de pensar. Ofrece otro dispositivo de Formación que habilita nuevas de experiencias para los docentes y para los alumnos. Aquellas que ponen en caución los tradicionales modos de escribir y de leer las prácticas de otros desde nuestros propios parámetros de lectura.

A mi juicio, este texto nos invita que preguntarnos, sobre todo, a través del análisis de las experiencias de otros, por la nuestra, por nuestros tiempos, los modos de enmarcar la comunicación del conocimiento didáctico en las instituciones de Formación Docente, por los modos de clasificarlos a través del disciplinamiento de los saberes en el concierto de lo que se considera legítimo enseñar y saber para llegar a enseñar.

El libro me ha invitado a advertir que la construcción del objeto de investigación construida no puede limitarse a mostrar las alternativas de enseñanza como si fueran cosas a describir, sino disparadores para volver a nuestros propios modos de enunciar y practicar la enseñanza en los ámbitos en los que transitamos. El conocimiento, entonces, devenido en práctica de reflexión de nuestras propias prácticas que ponen en jaque las marcas más 
fuertes con que la Didáctica ha construido sus discursos: la deshistorización, la ajenidad de los sujetos de sus prácticas, la heteronomía en la toma de decisiones en la relación con el conocimiento.

Tal como escribe Larrosa en Del espíritu del niño al niño del espíritu (2000). Allí este autor realiza una analogía entre formación y viaje, relación donde deshace la importancia concedida a la meta o al punto de llegada para concederla al mismo tránsito. El viajero, ávido por aprehender otras culturas y mundos y aprender de ellas, decide cambiar sus propios parámetros para poder ver más allá de sí mismo, para poder dar lugar a lo diferente. Este esfuerzo de conocimiento interrumpe los mismos modos de conocer/se, de pensar/se y de ver/se; ese tránsito que busca un encuentro con lo distinto permitirá no sólo advertir más de lo nuevo sino también más de lo propio en un juego de espejos que devuelven imágenes cambiadas. Y será ese recorrido, ahora también como experiencia que se toma el tiempo para narrarse, el que brinde la posibilidad de efectuar no sólo el reconocimiento del otro sino el de uno mismo como reflexión en y de una trayectoria de transformación. 


\section{Dossier}

Jornadas de Práctica Docente 
